\title{
REALIZACJA ZASADY ZRÓWNOWAŻONEGO ROZWOJU W POLITYCE EKOLOGICZNEJ POLSKI PO KONFERECJACH W RIO DE JANEIRO W 1992 ORAZ 2012 ROKU
}

\section{Wstęp}

Gwałtowny wzrost liczby ludności, dysproporcje w poziomie życia w różnych rejonach świata, nadzwyczajny rozwój klasy średniej, zwiększenie produkcji dóbr i usług oraz żywności, a także wyczerpywanie się surowców naturalnych, zwiększenie emisji $\mathrm{CO}_{2}$ oraz degradacja środowiska naturalnego spowodowały, że zaczęto poszukiwać alternatywnych metod rozwoju gospodarczego. Problem zmian w środowisku naturalnym zrodził się wraz z gwałtownym wzrostem gospodarczym. Aby sprostać nasilającym się problemom została opracowana koncepcja zrównoważonego rozwoju. Koncepcja ta zakłada, że przy zachowaniu dóbr środowiska naturalnego można nie hamować rozwoju gospodarczego. Treść koncepcji zrównoważonego rozwoju obejmuje zasadę sprawiedliwości, równości wewnątrz- i międzypokoleniowej oraz zasadę zrównoważonego korzystania z zasobów środowiska naturalnego. W zakresie ekologii przewiduje działania, które polegają na zmianie wzorców konsumpcji, a także stosowanie technologii przyjaznych środowisku, aby zachować zasoby naturalne ziemi. ${ }^{1}$ Zrównoważony rozwój jest niejako strategią, która stwarza możliwość powstrzymania katastrofy ekologicznej na Ziemi. Z drugiej zaś strony zajmuje się dysproporcjami w rozwoju pomiędzy różnymi częściami świata. Można wskazać, że jej głównym celem jest osiągnięcie globalnej sprawiedliwości zarówno w sposobie życia oraz dostępie do zasobów. ${ }^{2}$ Aby spełnić cele zrównoważonego rozwoju został opracowany szereg założen, które z jednej strony chcą umożliwić zaspokojenie potrzeb życiowych ludzi, przy jednoczesnym zapewnieniu 
ochrony biologicznej przyrody. Działania te mają zmierzać do zachowania bioróżnorodności, zachowania równości społecznej oraz dostatku zasobów naturalnych. Wspomniana równość społeczna nie oznacza natomiast, że wszyscy mają tyle samo, ale mają zagwarantowany taki sam dostęp do dóbr naturalnych, np. wody, ziemi, żywności, które mają zapewnić im spełnianie podstawowych potrzeb życiowych. Wyzwania związane z możliwością realizacji założeń zrównoważonego rozwoju są obserwowane już od lat 60. XX wieku. Ważne w tym zakresie jest jednak, że w celu ich osiągnięcia niezbędne jest skoordynowanie działań nie tylko na arenie międzynarodowej, ale i światowej.

Szczególne znaczenie w zakresie przyszłości naszej planety odegrała Konferencja w Rio de Janeiro, która miała miejsce w roku 1992. Dzięki temu wydarzeniu została rozwinięta koncepcja zrównoważonego rozwoju. Wydarzenie to otworzyło nowy etap. Zaczęto bowiem dyskutować o związkach rozwoju gospodarczego i ochrony środowiska. Efektem konferencji było opracowanie założeń do dalszych działań w zakresie zrównoważonego rozwoju. Wszechstronny plan działania na wiek XXI dla Organizacji Narodów Zjednoczonych, rządów państw oraz grup społecznych został opracowany w dokumencie Agenda 21. Dokument ten podejmuje kwestie ważne w każdym obszarze, w którym człowiek ma wpływ na środowisko. W szczycie uczestniczyli przedstawiciele 172 krajów, którzy zgodnie sygnowali Agendę 21. Została również podpisana Ramowa Konwencja Narodów Zjednoczonych w sprawie zmian klimatu. Jest to umowa międzynarodowa, która określa założenia w zakresie współpracy międzynarodowej dotyczącej ograniczenia emisji gazów cieplarnianych odpowiedzialnych za zjawisko globalnego ocieplenia. ${ }^{3}$

Postępujący kryzys gospodarczy, ubożenie wielu grup społecznych, wzrost bezrobocia oraz wyczerpywanie się złóż naturalnych sprawiły, że konieczne stało się wypracowanie nowych celów zrównoważonego rozwoju. W tym celu po dwudziestu latach od konferencji w Rio de Janeiro ONZ zwołało nowy szczyt, który funkcjonuje pod nazwą Rio+20.

Celem artykułu jest próba oceny postanowień zawartych podczas obu konferencji w Rio dla realizacji celów zrównoważonego rozwoju w polityce ekologicznej Polski. W dalszej części zostanie przeanalizowane, w jaki sposób zasady zrównoważonego rozwoju zostały wprowadzone do prawodawstwa krajowego, jakie akty prawne regulują tę kwestię w kontekście polityki ekologicznej, a także jakie dziedziny obejmują. Zwrócenie uwagi na politykę ekologiczną Polski w zakresie zrównoważonego rozwoju jest aktualnie bardzo ważnym tematem, którego celem jest gwarancja rozwoju gospodarczego przy zachowaniu środowiska naturalnego. Potrzebne będzie również wskazanie barier, które utrudniają realizację jednolitej polityki zrównoważonego rozwoju. Na koniec spróbuję odpowiedzieć na pytanie, czy 
Realizacja zasady zrównoważonego rozwoju w polityce ekologicznej Polski...

rzeczywiście postanowienia zawarte podczas Konferencji w Rio de Janeiro miały wpływ na kształtowanie i wdrażanie zasad zrównoważonego rozwoju.

\section{Postanowienia Konferencji Narodów Zjednoczonych w Rio de Janeiro}

Aby móc ocenić realizację polityki ekologicznej Polski w kontekście efektów konferencji w Rio de Janeiro na wstępie zasadne wydaje się przytoczenie najważniejszych założeń oraz podjętych zobowiązań w zakresie polityki ekologicznej.

Pierwsza konferencja miała miejsce w Rio de Janeiro w dniach 3-14 czerwca 1992 roku. W tamtym okresie było to jedno z największych spotkań na forum międzynarodowym. Najważniejszym tematem obrad był problem zrównoważonego rozwoju. Szczyt Ziemi uświadomił wzrastającą świadomość ekologiczną oraz wskazał wagę globalną problemu, związaną z postępującymi zmianami w środowisku naturalnym, które bezpośrednio powiązano z gwałtownym wzrostem gospodarczym. Konwencja wniosła nowe, a zarazem bardzo ważne założenia ideowe, których zadaniem było kształtowanie nowych programów rozwojowych, a także rozwiązań w zakresie ochrony środowiska. ${ }^{4}$ Efektem konferencji było przyjęcie dokumentów, które miały stanowić wytyczne dla państw w niej uczestniczących na przyszłe lata. Dokumentami tymi były: Deklaracja z Rio - zbiór zasad dotyczący przyszłego rozwoju oraz zobowiązań w zakresie ochrony środowiska, wspomniany wcześniej dokument Agenda 21 - program działań na rzecz współpracy w dziedzinie rozwoju i ochrony środowiska, Ramowa Konwencja Narodów Zjednoczonych w sprawie zmian klimatu - dokument poruszający problem efektu cieplarnianego oraz program jego ograniczenia, jak też zapobiegania jego skutkom poprzez zmniejszenie emisji gazów cieplarnianych, Deklaracja zasad gospodarki leśnej - dokument uwzględniający znaczenie gospodarcze, ekologiczne i kulturowe lasów. ${ }^{5}$ Dokumentem uważanym za jeden z najważniejszych przyjętych w trakcie trwania Konferencji jest Deklaracja z Rio w sprawie środowiska i rozwoju, która składa się z 27 zasad, stanowiących normy w zakresie ochrony środowiska oraz zrównoważonego rozwoju. Deklaracja w centrum zainteresowania stawia człowieka. Również jako pierwszą i nadrzedną zasadę Deklaracji stanowi prawo człowieka do zdrowego i twórczego życia w harmonii z przyrodą. Pozostałe zasady odnoszą się bezpośrednio do państw, w zakresie ich zadań, polityki zewnętrznej i wewnętrznej oraz stanowionego prawa. ${ }^{6}$ Konferencja była uznawana jako zdecydowane zobowiązanie państw w ochronie środowiska o globalnym charakterze oraz dążenie do zapewnienia światowego bezpieczeństwa. Najważniejsze dokumenty miały charakter ogólnych deklaracji, nie został w nich

\footnotetext{
$4 \quad$ Z. Bukowski, Zrównoważony..., op. cit., s. 80.

5 E. Berkowska, M. Sobolewski, Realizacja polityki ekologicznej w kontekście postanowień Szczytu ziemi w Rio, „Biuro Studiów i Ekspertyz” 1995, Informacja Nr 291, s. 3-5.

$6 \quad$ Z. Bukowski, Zrównoważony..., op. cit., s. 84-85.
} 
sprecyzowany program ustalający harmonogram działań i jasne kryteria. Realizacja postanowień wypracowanych w trakcie trwania Konferencji zależała wyłącznie od dobrej woli poszczególnych państw. Podkreślić trzeba, że dokumenty te nie zawierały żadnych sankcji wobec krajów nie podejmujących się wdrożenia w życie ustaleń Szczytu Ziemi. ${ }^{7}$

Dwadzieścia lat po pierwszej Konferencji w Rio de Janeiro w dniach 20-22 czerwca 2012 roku odbyło się kolejne spotkanie Szefów Państw i Rządów, którego celem było odnowienie postulatów i założeń dokonanych w zakresie zrównoważonego rozwoju oraz w celu zapewnienia działań na rzecz zrównoważonego rozwoju na rzecz obecnych i przyszłych pokoleń.

Na szczycie przyjęta została deklaracja Przyszłość jaka chcemy mieć. W 280 artykułach, z których się składa państwa uczestniczące w konferencji wyraziły zobowiązania na rzecz zrównoważonego rozwoju w trzech płaszczyznach: ekonomicznej, społecznej i środowiskowej. ${ }^{8}$

W myśl założeń Rio+20 ekorozwój przejawia się m.in. realizacją inwestycji prowadzących do zrównoważonego zarządzania kluczowymi zasobami środowiska i kapitałem naturalnym, który bez troski społeczeństwa będzie kurczył się bez szansy przetrwania dla przyszłych pokoleń. W koszyku kapitału, o który walczy idea Rio+20 znajdują się: zasoby wodne i morskie, troska o odnawialne źródła energii, realizowanie usług ekosystemowych, gospodarka odpadami i recykling. Podczas Rio+20 alarmowano, że każdy obywatel może i powinien walczyć o środowisko, w którym żyje. Każdy z nas może przyczynić się do eliminacji ubóstwa, jeśli tylko wykorzystamy potencjał, jaki drzemie w ekologicznym korzystaniu z zasobów ziemi. Podejście do tego przesłania jest różne - dla jednych to patetycznie wyrażona intencja chęci wzbogacenia się na zrównoważonym rozwoju, dla innych szczerze wyrażona idea walki o garść zdrowego życia w ekologicznym środowisku, która jeszcze pozostała w naszych dłoniach. ${ }^{9}$

Założenia konferencji Rio+20 opierały się głównie na ,ukierunkowaniu deklaracji politycznej”, która miała za zadanie określenie wspólnej dla uczestniczących państw wizji w kierunku głębokich przemian gospodarki ekologicznej. W osiągnięciu tych założeń miało pomóc określenie konkretnych celów oraz uzgodnienie terminów ich realizacji. Pilna potrzeba w określeniu ram instytucjonalnych miała pomóc w realizacji zrównoważonego rozwoju w skali światowej. Sukces konferencji Rio+20 miał opierać się na stworzeniu ram oraz powiązaniu kwestii eliminacji ubóstwa, wykorzystania zasobów naturalnych oraz degradacji środowiska. Zrównoważony rozwój mógłby zostać zagwarantowany zarówno przez dobrze funkcjonujący rynek oraz eliminację ubóstwa, ale także poprzez wprowadzenie skutecznych

E. Berkowska, M. Sobolewski, Realizacja..., op. cit., s. 3-5.

Dokument końcowy Konferencji Organizacji Narodów Zjednoczonych z dnia 20-22 czerwca 2012 r. „Przyszłość jakiej chcemy".

9 Ibidem. 
przepisów. Przyjęcie rozwiązań w zakresie zrównoważonej energii, wody, degradacji gleb i ekosystemów, środowiska morskiego oraz efektywności wykorzystywania zasobów może być pierwszym krokiem w osiągnięciu innych założeń konferencji w zakresie ograniczenia ubóstwa oraz niwelowania różnic pomiędzy bogatymi i biednymi. ${ }^{10}$

W dokumencie końcowym konferencji Organizacji Narodów Zjednoczonych Rio+20 podkreślano, że kierunek prowadzenia polityki zielonej gospodarki powinien uwzględniać wszystkie opracowane dotychczas zasady, m.in. z Rio z 1992 roku, Agendę 21, Plan Implementacyjny z Johanesburga oraz powinien przyczyniać się do osiągnięcia celów rozwoju. W ramach polityki ekologicznej potwierdzone zostało wsparcie dla kierunków polityki oraz strategii na poziomie krajowym oraz subkrajowym, które przy wykorzystaniu odpowiedniej struktury źródeł energii będą spełniać potrzeby w zakresie zwiększenia wykorzystywania odnawialnych źródeł energii oraz innych technologii niskoemisyjnych, bardziej efektywnego wykorzystania energii, większego zakresu użycia zaawansowanych technologii energetycznych m.in. czystszych technologii opartych na paliwach kopalnych i zrównoważonego wykorzystania tradycyjnych zasobów energetycznych. Założenia w tym zakresie wzywają również władze do tworzenia korzystnych warunków ułatwiających inwestycje dla inwestycji sektora publicznego i prywatnego w odpowiednie i potrzebne czystsze technologie energetyczne.

Podkreślano, że największym zagrożeniem, a jednocześnie największym wyzwaniem jest gwałtowny wzrost emisji gazów cieplarnianych oraz fakt, że wszystkie kraje są narażone na negatywne oddziaływanie zmian klimatu. Skutki tych zmian obserwuje się w postaci m.in. trwałych susz i ekstremalnych zdarzeń pogodowych, erozji przybrzeżnej i zakwaszenia oceanów, które powodują, że stopień zagrażający bezpieczeństwu żywnościowemu oraz ubóstwie społeczeństwa jest jeszcze większy. Adaptacja do zmian klimatu ma stanowić bezpośredni i pilny priorytet globalny.

Podkreślano, że zwiększenie udziału energii odnawialnej, podniesienie efektywności energetycznej oraz czystsze i efektywne energetycznie technologie są ważne dla zrównoważonego rozwoju m.in. pod względem ograniczenia zmian klimatu. Zadaniem dla rządów państw jest również promowanie bodźców zachęcających do podniesienia efektywności energetycznej i wyeliminowania bodźców zniechęcających do jej podniesienia. Działania, które będą wprowadzać zasadę zrównoważonej energii przyczynią się również do eliminacji innych zagrożeń, które niesie za sobą globalny rozwój gospodarczy, w tym eliminacja ubóstwa.

W postulacie 191. podkreślano, że globalny charakter zmian klimatu wymaga możliwie jak najszerszej współpracy wszystkich krajów i ich udziału w efektywnej

10 Sprawozdanie z międzyparlamentarnego posiedzenia komisji nt. Przygotowań do konferencji Rio+20, Parlament Europejski, Bruksela, 21 marca 2012, przygotowane przez Kancelarię Senatu. 
i odpowiedniej reakcji międzynarodowej w celu przyspieszenia redukcji globalnej emisji gazów cieplarnianych. ${ }^{11}$

\section{Realizacja zasad zrównoważonego rozwoju w polityce ekologicznej Polski}

Jak zostało to już wcześniej wskazane, zarówno konferencja z Rio de Janeiro z 1992 roku oraz Rio +20 były ze sobą ściśle powiązane. Pomimo że celem Szczytu Ziemi, który miał miejsce w 2012 roku było opracowanie nowych celów w zakresie zrównoważonego rozwoju, to z postulatu 16. dokumentu Przyszłość jakiej chcemy jasno wynika, że państwa uczestniczące $w$ Konferencji ONZ potwierdzają dalszą chęć wdrożenia m.in. deklaracji z Rio z 1992 roku oraz programu Agenda 21. Celowe zatem stało się omówienie polityki Polski po 1992 roku łącznie.

W Polsce zasady dotyczące zrównoważonego rozwoju po raz pierwszy przedstawiono jeszcze przed Konferencją w Rio z 1992 roku. W dokumencie Polityka ekologiczna państwa, przyjętym przez Sejm Uchwałą z dnia 10 maja 1991 r. wyrażono wolę, aby polityka rządu we wszystkich dziedzinach gospodarczych była zgodna z założeniami polityki ekologicznej, a kryteria ekologiczne uzyskały równoznaczną rangę z kryteriami ekonomicznymi. ${ }^{12}$

Polska aktywnie uczestniczyła zarówno w przygotowaniach, jak i w samym Szczycie Ziemi w 1992 roku oraz 2012 roku. Konwencja o zmianach klimatu została przyjęta przez Polskę w 1994 roku. I to właściwie od tego czasu należy liczyć realizację i wdrażanie w życie przez nasz kraj zasad zrównoważonego rozwoju. Przyjęcie przez Polskę dokumentów końcowych po Szczycie Ziemi w 1992 roku sprawiło, że zobowiązano się do realizacji polityki ekorozwoju, co podniosło znaczenie naszego kraju na arenie międzynarodowej. ${ }^{13}$

Polska polityka ekologiczna po Szczytach Ziemi w Rio de Janeiro kształtuje się w kilku obszarach: zmian klimatu i ochrony powietrza, energii, ekosystemów morskich, użytkowania gruntów, gospodarki leśnej oraz bioróżnorodności i gospodarki odpadami.

Miejsce zrównoważonego rozwoju w polskim prawie należy rozważać pod kątem ujęcia tej zasady w ustawie zasadniczej - Konstytucji Rzeczypospolitej Polskiej. Momentem przełomowym w prawodawstwie polskim było wprowadzenie koncepcji zrównoważonego rozwoju jako zasady konstytucyjnej. W myśl art. 5 Konstytucji Rzeczypospolitej Polskiej z dnia 2 kwietnia 1997 r. stwierdza się, że Rzeczpospolita Polska strzeże niepodległości i nienaruszalności swojego terytorium, zapewnia wolność i prawa człowieka i obywatela oraz bezpieczeństwo obywateli, strzeże

\footnotetext{
11 Dokument końcowy Konferencji Organizacji Narodów Zjednoczonych z dnia 20-22 czerwca 2012 r. „Przyszłość jakiej chcemy".

12 E. Berkowska, M. Sobolewski, Realizacja..., op. cit., s. 6-7.

13 Ibidem, s. 6-7.
} 
dziedzictwa narodowego oraz zapewnia ochronę środowiska, kierując się zasadą zrównoważonego rozwoju. Również w art. 74 nawiązano do bezpieczeństwa ekologicznego oraz zasad zrównoważonego rozwoju. Władze publiczne zostały w ten sposób zobowiązane do zapewnienia bezpieczeństwa ekologicznego obecnym oraz przyszłym pokoleniom. ${ }^{14}$

Zasady zrównoważonego rozwoju najszerzej zostały omówione w aktach prawnych z zakresu ochrony środowiska. Za podstawowy dokument można uznać ustawę z dnia 27 kwietnia 2001 roku Prawo ochrony środowiska, w której została również zawarta definicja zrównoważonego rozwoju. Art. 3 definiuje go jako taki rozwój społeczno-gospodarczy, w którym następuje proces integrowania działań politycznych, gospodarczych i społecznych, z zachowaniem równowagi przyrodniczej oraz trwałości podstawowych procesów przyrodniczych, w celu zagwarantowania możliwości zaspokajania podstawowych potrzeb poszczególnych społeczności lub obywateli zarówno współczesnego pokolenia, jak i przyszłych pokoleń. ${ }^{15}$

Nowym, ważnym impulsem na tej drodze okazała się perspektywa przystąpienia Polski do Unii Europejskiej. Przepisy Traktatu Akcesyjnego stawiały naszemu krajowi poważne zadania do wypełnienia, z generalną tezą, że po roku 2015 Rzeczpospolita Polska powinna być krajem spełniającym wszystkie standardy w ochronie środowiska, obowiązujące w krajach członkowskich UE.

Wspomniana wcześniej ustawa Prawo ochrony środowiska w dziale III określa zasady polityki ekologicznej państwa wskazując programy z zakresu ochrony środowiska. Na państwo został również nałożony obowiązek opracowywania polityki ekologicznej. Zgodnie z art. 14 ustawy Prawo ochrony środowiska, polityka ekologiczna opracowywana jest na podstawie aktualnego stanu środowiska i w szczególności ma za zadanie określenie celów i priorytetów ekologicznych, rodzaj i harmonogram działań proekologicznych oraz środki, które są niezbędne do określenia tych celów. Do środków tych można zaliczyć mechanizmy prawno- ekonomiczne oraz środki finansowe. Ustawa określa również, że polityka ekologiczna jest przyjmowana na okres 4 lat, z perspektywą obejmowania 4 kolejnych lat. Uchwalana jest przez Sejm na wniosek Rady Ministrów. ${ }^{16}$

Obecnie szczegółowo polską politykę ochrony środowiska określa dokument Polityka ekologiczna państwa w latach 2009-2012 z perspektywą do roku $2016 .{ }^{17}$ W polityce ekologicznej zostały sformułowane główne cele, do realizacji których będzie dążył nasz kraj. Celem strategicznym tego dokumentu jest zapewnienie bezpieczeństwa ekologicznego kraju, mieszkańców, zasobów przyrodniczych, infrastruktury społecznej oraz tworzenie podstaw zrównoważonego rozwoju społeczno-gospodarczego.

Konstytucja Rzeczpospolitej Polskiej z dnia 2 kwietnia 1997 r., Dz.U. Nr 78, poz. 483 ze zm.

Ustawa Prawo ochrony środowiska z dnia 27 kwietnia 2001 r., Dz.U. Nr 62, poz. 627.

Ibidem.

Polityka ekologiczna państwa w latach 2009-2012 z perspektywą do roku 2016, Warszawa 2008. 
Za dokument wyjściowy można uznać dokument zawierający koncepcję długookresowej strategii zrównoważonego rozwoju Polski do 2025 roku. Zapisano w nim, że stan i zasoby środowiska stanowią jeden z najważniejszych czynników, które będą decydować o warunkach i możliwości rozwoju Polski w XXI wieku. ${ }^{18}$ Jednakże Strategia zrównoważonego rozwoju Polski do roku 2025 jest w chwili obecnej aktem nieobowiązującym, który został uchylony przez Radę Ministrów dnia 23 października 2007 roku.

Omawiając obszary polityki ekologicznej RP można zacząć od zmian klimatu. Dokumentem, który został opracowany na podstawie zaleceń ujętych w Ramowej Konwencji Narodów Zjednoczonych w sprawie zmian klimatu oraz Protokołu z Kioto podpisanym po Konferencji w Rio de Janeiro z 1992 roku jest Polityka klimatyczna Polski - Strategie redukcji emisji gazów cieplarnianych w Polsce do roku 2020. Strategiczna polityka klimatyczna jest dokumentem, który miał pomóc włączyć się Polsce do wysiłków społeczności międzynarodowej na rzecz ochrony klimatu globalnego poprzez wdrażanie zasad zrównoważonego rozwoju. ${ }^{19}$ Głównym celem działań określonych przez ten dokument jest wdrożenie państwowej strategii redukcji emisji gazów cieplarnianych. Strategia ta ma za zadanie m.in. poprawę efektywności energetycznej gospodarki, ochronę pochłaniania i retencjonowania gazów cieplarnianych poprzez promowanie zrównoważonej gospodarki leśnej, promowania zrównoważonych form rolnictwa, promowania i wdrażania technologii wykorzystujących odnawialne źródła energii, pochłaniających dwutlenek węgla itp., stopniowej redukcji barier rynkowych, utrudniających redukcję emisji w sektorach gospodarczych, w tym usuwania dotacji i wprowadzania ulg podatkowych. Głównym celem polityki klimatycznej Polski jest pogłębienie skali redukcji emisji gazów cieplarnianych do poziomu $40 \%$ do roku $2020 .^{20}$

Kolejnym obszarem Polskiej polityki ekologicznej jest energia. Bardzo duże znaczenie w tym zakresie odgrywa rozwój energetyki odnawialnej oraz realizacja podstawowych kierunków działań. Wykorzystanie odnawialnych źródeł energii niesie za sobą nie tylko poprawę efektywności zużycia energii, ale również zmniejsza uzależnienie naszego kraju od dostaw importowanej energii. Obszar ten aktualnie przyjmuje coraz szybszy tryb rozwoju w kierunku zwiększenia dostaw energii pozyskiwanej z OZE. Aktualnie najważniejszym aktem prawnym w zakresie polityki energetycznej państwa jest ustawa z dnia 10 kwietnia 1997 roku Prawo energetyczne. ${ }^{21}$ Pierwszą regulacją dotyczącą odnawialnych źródeł energii było rozporządzenie Ministra Gospodarki z dnia 2 lutego 1999 roku w sprawie obowiązku zakupu energii elektrycznej i ciepła ze źródeł niekonwencjonalnych oraz zakresu tego obowiązku

18 Strategia zrównoważonego rozwoju Polski do 2025 roku, Warszawa, grudzień 1999 r.

19 Z. Bukowski, Zrównoważony..., op. cit., s. 509.

20 Polityka klimatyczna Polski. Strategie redukcji emisji gazów cieplarnianych w Polsce do roku 2020, przyjęta przez Radę Ministrów dnia 4 listopada 2003 r., s. 15-16.

21 Ustawa Prawo energetyczne z dnia 10 kwietnia 1997 roku, Dz.U. Nr 54, poz. 348 z późn. zm. 
(Dz.U. z 1999 r. Nr 13, poz. 119). Rozporządzenie to zostało zmienione rok później, natomiast w wyniku nowelizacji z dnia 1 stycznia 2003 roku art. 9a ustawy Prawo energetyczne, zostało zastąpione nowym rozporządzeniem Ministra Gospodarki Pracy i Polityki Społecznej z dnia 30 maja 2003 r. (Dz.U. Nr 104, poz. 971). Zakres zmian wprowadził obowiązek zakupu energii elektrycznej pozyskanej z naturalnych źródeł przez wszystkie przedsiębiorstwa zajmujące się obrotem energii elektrycznej. Przedsiębiorstwa te zostały dodatkowo zobligowane do zapewnienia w sprzedaży odpowiedniego udziału energii OZE. ${ }^{22}$

Od 2006 roku odnotowuje się nieznaczny wzrost udziału energii ze źródeł odnawialnych w końcowym jej zużyciu. ${ }^{23}$ Założenia na przyszłe lata określają stopień wykorzystania tego źródła w końcowym zużyciu energii brutto na poziomie $15 \%$ do 2020 roku i $20 \%$ do 2030 roku. Ponieważ pozyskiwanie energii z odnawialnych źródeł energii można uznać za najbardziej rozwijającą się aktualnie dziedzinę, to również kwestie prawne w tym zakresie odgrywają znaczącą rolę. Podstawowym dokumentem określającym kierunki polityki energetycznej kraju jest Polityka energetyczna Polski do 2030 r. Głównym celem i założeniem przyjętym w tym dokumencie jest zwiększenie bezpieczeństwa energetycznego kraju przy zachowaniu zasad zrównoważonego rozwoju. Główne cele polityki energetycznej obejmują wzrost wykorzystania odnawialnych źródeł energii w bilansie energii finalnej do $15 \% \mathrm{w}$ roku 2020 i 20\% w roku 2030. Jednym z głównych celów opracowanym w omawianym dokumencie jest ochrona lasów przed nadmiernym eksploatowaniem w celu pozyskiwania biomasy oraz zrównoważone wykorzystywanie obszarów rolniczych na cele OZE, w tym biopaliw, tak aby nie doprowadzić do konkurencji pomiędzy energetyką odnawialną i rolnictwem oraz zachować różnorodność biologiczną. ${ }^{24}$

Proces integracji z Unią Europejską zobowiązał nasz kraj do podejmowania działań w zakresie uzyskiwania energii ze źródeł odnawialnych, z drugiej natomiast strony stało się to okazją do skorzystania z pomocy Wspólnoty. W tym celu została opracowana Strategia rozwoju energetyki odnawialnej. Dokument ten zakłada wzrost udziału energii ze źródeł odnawialnych w bilansie paliwowo-energetycznym kraju do 7,5\% w 2010 r. i do 14\% w 2020 r., w strukturze zużycia nośników pierwotnych. Wzrost wykorzystania odnawialnych źródeł energii (OZE) ułatwi przede wszystkim osiągnięcie założonych w polityce ekologicznej celów w zakresie obniżenia emisji zanieczyszczeń odpowiedzialnych za zmiany klimatyczne oraz substancji zakwaszających. ${ }^{25}$

Brak w polskim systemie prawnym jednolitego aktu, który regulowałby kwestie energii ze źródeł odnawialnych oraz fakt, że większość państw Unii Europejskiej

23 Wskaźniki zrównoważonego rozwoju Polski, dokument opracowany przez Urząd Statystyczny w Katowicach, Katowice 2011, s. 122.

24 Polityka energetyczna Polski do 2030 roku, dokument przyjęty przez Radę Ministrów w dniu 10 listopada 2009 r., s. 19.

25 Strategia rozwoju energetyki odnawialnej, Warszawa, wrzesień 2000, s. 12-13. 
uchwaliła ustawę, która umożliwia gwarancję rozwoju energii odnawialnej sprawiły, że w dniu 8 kwietnia 2014 roku została przyjęta przez Radę Ministrów ustawa o odnawialnych źródłach energii. W dalszym ciągu trwają jednak prace nad jej ostatecznym kształtem.

Kolejnym obszarem jest pozyskiwanie energii odnawialnej z wykorzystaniem biopaliw. Rosnąca liczba środków transportu i idąca za tym potrzeba ochrony środowiska naturalnego sprawiły, że zaczęto poszukiwać nowych rozwiązań, które będą się cechowały niewielką bądź zerową emisją zanieczyszczeń. Obserwowany jest w Polsce wzrost wykorzystywania źródeł odnawialnych przy produkcji paliw. Aby osiągnąć zwiększony udział biopaliw Polska opracowała sobie wytyczne, które zakładają osiągnięcie w 2020 roku 10\%, a do 2030 r. 10,4\% udziału biopaliw w rynku paliw transportowych. ${ }^{26}$

W obszarze gospodarki leśnej podstawowe znaczenie odgrywa ustawa z dnia 28 września 1991 r. o lasach. ${ }^{27}$ Zostały w niej określone zasady zachowania, ochrony i powiększania zasobów leśnych, a także zasady gospodarki leśnej w powiązaniu z innymi elementami środowiska i gospodarki narodowej. W ustawie o lasach zwraca się szczególną uwagę na cele trwale zrównoważonej gospodarki leśnej poprzez zachowanie lasów i ich korzystnego wpływu na klimat, powietrze, wodę, glebę, warunki życia i zdrowia człowieka oraz na równowagę przyrodniczą.

W obszarze gospodarki odpadami, podstawowe znaczenie odgrywa ustawa o odpadach z dnia 14 grudnia 2012 roku. ${ }^{28}$ Określa ona zasady postępowania z odpadami w sposób zapewniający ochronę życia i zdrowia ludzi oraz ochronę środowiska zgodnie z zasadą zrównoważonego rozwoju, a w szczególności określa zasady powstawania odpadów lub ograniczania ilości odpadów i ich negatywne oddziaływania na środowisko, a także odzysku lub unieszkodliwiania odpadów. Wskazuje się, że odwołanie się do zasady zrównoważonego rozwoju jest najbardziej istotnym postanowieniem w tej ustawie. Jego istotą jest zapewnienie bezpieczeństwa ekologicznego, które jako element zrówównoważonego rozwoju odgrywa bardzo ważną rolę. ${ }^{29}$

Aktem prawnym, który również odnosi się do zasad zrównoważonego rozwoju jest ustawa z dnia 27 marca 2003 roku o planowaniu i zagospodarowaniu przestrzennym. ${ }^{30}$ Przyjmuje się ją za podstawę działań w zakresie dotyczącym zasad kształtowania polityki przestrzennej oraz sposobu postępowania w sprawach przeznaczenia terenów na określone cele. Koncepcję przestrzennego zagospodarowania kraju należy sporządzać z uwzględnieniem zasady zrównoważonego rozwoju kraju w oparciu o przyrodnicze, kulturowe, społeczne i ekonomiczne uwarunkowania.

\footnotetext{
26 Polityka energetyczna Polski do 2030 roku, op. cit., s. 12.

27 Ustawa o lasach z dnia 28 września 1991 roku, Dz.U. Nr 101, poz. 444 z późn. zm.

28 Ustawa o odpadach z dnia 14 grudnia 2012 r., Dz.U. z 2013 r., poz. 21.

29 Z. Bukowski, Zrównoważony..., op. cit., s. 477.

30 Ustawa o planowaniu i gospodarowaniu przestrzennym z dnia 27 marca 2003 r., Dz.U. Nr 80, poz. 717.
} 
Do aktów prawnych wspierających stosowanie zasad zrównoważonego rozwoju w polityce ekologicznej zaliczana jest również ustawa z dnia 3 października 2008 roku o udostępnianiu informacji o środowisku i jego ochronie, udziale społeczeństwa w ochronie środowiska oraz o ocenach oddziaływania na środowisko. ${ }^{31}$ Ustawa ta jest aktem prawnym, który implementuje do krajowego systemu prawnego dyrektywy Unijne w sprawie ochrony środowiska naturalnego. Ustawa ta określa zasady i tryb postępowania $w$ sprawach $\mathrm{z}$ zakresu udostępniania informacji o środowisku i jego ochronie, oceny oddziaływania na środowisko, zasady udziału społeczeństwa w ochronie środowiska.

Występowanie zasady zrównoważonego rozwoju w Konstytucji RP, a także w ustawach zwykłych świadczy, że ma ona charakter wiążący. ${ }^{32}$ To akty prawne określają rolę zrównoważonego rozwoju w polskim systemie prawnym. Osiągnięcie zamierzonych celów będzie mozliwe dzięki współpracy społeczeństwa, samorządów, administracji państwowej i jej działów, Parlametu i Głowy Państwa. Słuszny zatem i konieczny będzie również dalszy rozwój mechanizmów prawnych, ekonomicznych i technicznych w zakresie zrównoważonego rozwoju. Niestety, wiele z nich wciąż pozostaje niekompletnych w zakresie trzech głównych wymiarów rozwoju, czyli ekonomicznego, ekologicznego i społecznego. ${ }^{33}$

Należy zauważyć, że pomimo tego, iż problem wdrażania zasad zrównoważonego rozwoju ma znaczenie globalne, to trzeba podkreślić, że europejską drogę zmierzającą do osiągnięcia wydajności zasobów kształtuje Unia Europejska. To dyrektywy unijne wyznaczają wartość wskaźników, które muszą zostać osiągnięte przez nasz kraj na przestrzeni lat.

Udział Polski w Konferencji Narodów Zjednoczonych sprawia, że nasz kraj staje się partnerem w realizacji zasad zrównoważonego rozwoju na arenie międzynarodowej. $Z$ treści dokumentów podsumowujących Szczyty Ziemi w Rio de Janeiro, zarówno w 1992 oraz 2012 roku, nie wynikają żadne restrykcje ani prawne, ani finansowe, ani żadne inne, które byłyby siłą napędową dla rządów państw, które się pod nimi podpisują.

Analizując przebieg konferencji Rio+20 można wywnioskować, że jej postanowienia kierowane są do poszczególnych państw członkowskich, a te rozdzielają idee pomiędzy własne jednostki samorządu terytorialnego do realizacji. Tak samo dzieje się również w Polsce, gdzie poprawę zarządzania dedykuje się w realizacji sektorowi prywatnemu, tj. małym i średnim przedsiębiorstwom, które uczestniczą i angażują się w działania na rzecz ekorozwoju regionu, w którym funkcjonują.

\footnotetext{
31 Ustawa o udostępnianiu informacji o środowisku i jego ochronie, udziale społeczeństwa w ochronie środowiska oraz o ocenach oddziaływania na środowisko z dnia 3 października 2008 roku, Dz.U. Nr 199, poz. 1227.

32 J. Kielin- Maziarz, Koncepcja..., op. cit., s. 58.

33 Z. Bukowski, Zrównoważony..., op. cit., s. 526.
} 


\section{Podsumowanie}

Wzrost liczby ludności do 9 mld w 2050 roku, osiągnięcie w 2030 roku 3 mld osób należących do klasy średniej doprowadzi nie tylko do wzrostu zapotrzebowania na różne rodzaje produktów, ale także może doprowadzić do olbrzymiej degradacji środowiska naturalnego. Konferencje w Rio de Janeiro w 1992 oraz 2012 roku miały za zadanie poruszenie bardzo ważnego tematu, którym jest dążenie do zapewnienia przyszłym pokoleniom takich warunków, które będą mogły zapewnić im byt. Do osiągnięcia założeń wypracowanych w trakcie trwania konferencji może się przyczynić tylko wzajemna współpraca wszystkich krajów.

Zasadniczym celem zrównoważonego rozwoju w kontekście ekologicznym jest podejmowanie takich działań, które z jednej strony będą przyczyniały się do ochrony środowiska naturalnego poprzez wykorzystanie naturalnych źródeł energii, ochronę wód, gruntów i lasów, zmniejszenie emisji gazów cieplarnianych. Ważne jest, aby w zakresie tych działań przyczyniać się do tworzenia nowych miejsc pracy, zwiększać rozwój lokalny oraz działalności towarzyszące tej produkcji, wykorzystywać nieużytki, a także zagospodarować nadwyżki.

Trzeba również podkreślić, że zrównoważony rozwój nie jest ochroną środowiska w tradycyjnym znaczeniu. Faktycznie odbywa się on w przestrzeni ekologicznej, jednakże poprzez kooperację czynników ekonomicznych, środowiskowych, społecznych i gospodarczych jego efekty są dostrzegalne w każdej z wymienionych dziedzin. Zrównoważony rozwój stanowi wyzwanie do zachowania rozwagi i rozumu w każdej płaszczyźnie życia.

Nie tylko przyjęcie założeń konwencji z Rio, ale również obecność Polski w strukturach Unii Europejskiej oraz ONZ narzuciły na nasz kraj obowiązek wprowadzania rozwiązań prawnych i technologicznych, które są zgodne z założeniami zrównoważonego rozwoju. Ocenę wywiązywania się naszego kraju z wprowadzania uregulowań prawnych poruszających kwestię zrównoważonego rozwoju w kształtowaniu polityki ekologicznej kraju należy określić pozytywnie.

Bardzo ważne jest przy tej okazji kształtowanie pozytywnych wizji społecznych, które pomogą w drodze do osiągnięcia zamierzonych celów. Takie założenia podkreślano również na konferencji w Rio de Janeiro, aby wdrażając zasady zrównoważonego rozwoju aktywnie zaangażować nie tylko sektor publiczny, ale również prywatny. Uznano bowiem, że aktywny udział sektora prywatnego może przyczynić się do osiągnięcia zrównoważonego rozwoju m.in. dzięki takim narzędziom, jakim jest partnerstwo publiczno - prywatne.

Realizacja postulatów w zakresie zrównoważonego rozwoju przez nasz kraj jest bardzo trudna. $Z$ jednej strony występujący kryzys finansowy niejako blokuje zaangażowanie środków finansowych $\mathrm{w}$ realizację podstawowych celów, $\mathrm{z}$ drugiej natomiast strony uwarunkowania gospodarki sprawiają, że działania muszą uwzględniać interesy nie tylko sfery rządzącej, ale również innych uczestników rynku. Rów- 
nież skala wyzwań, jaka została postanowiona w czasie trwania konferencji jest tak ogromna, że bardzo trudno będzie odnieść wymierne i widoczne w najbliższym czasie efekty i oczekiwania.

Należy stwierdzić, że pomimo wysokiej rangi, jaką nadano zasadzie zrównoważonego rozwoju przywoływaniu tej koncepcji w wielu ustawach i dokumentach rządowych należy podjąć szerokie działania związane głównie z tworzeniem szeregu instrumentów wspierających, aby zasada zrównoważonego rozwoju była powszechnie stosowana w działaniach społecznych i gospodarczych w Polsce.

Koncepcja ekologicznej gospodarki wyrażona na szczycie Rio+20 prowadzi do zrównoważonego zarządzania kapitałem naturalnym i dystrybucją dostępnych dóbr w sposób sprzyjający zagwarantowaniu obywatelom i przyszłym pokoleniom korzystania $\mathrm{z}$ potencjału środowiska naturalnego. W fundamentach tego założenia spoczywają działania na rzecz ekoenergii elektrycznej. Jednakże dla naszego kraju to Unia Europejska kształtuje kierunek polityki ekologicznej. Unia Europejska narzuca realizację określonych celów, m.in. zmniejszanie emisji $\mathrm{CO}_{2}$, redukcję efektu cieplarnianego, wykorzystywanie naturalnych źródeł energii, zwiększanie bioróżnorodności. To Unia Europejska określa wysokość wskaźników, które muszą być osiągnięte przez państwa członkowskie.

Konferencje Organizacji Narodów Zjednoczonych w Rio de Janeiro podniosły bardzo ważną kwestię, jaką jest ochrona zasobów naturalnych na całym świecie. Jednakże podkreślić należy, że brak sankcji dla krajów, które podpisały się pod postulatami i celami opracowanymi w czasie trwania konferencji sprawia, że w ostatecznym rozrachunku okażą się fiaskiem na skalę światową. Dokumenty końcowe konferencji nie wskazują żadnych konkretnych wytycznych do wypracowania, które stałyby się argumentem do oceny stopnia, w jakim nastąpiła realizacja założeń Szczytu Ziemi. Zadania te zostały pozostawione dla rządów państw, które powinny opracować krajowe plany działań w zakresie zrównoważonego rozwoju. Istotny może okazać się również udział w realizacji tych zadań wpływowych grup społecznych oraz podmiotów gospodarczych, które przy okazji znajdą źródło zysku. Bez radykalnych zmian w tym zakresie za kilkadziesiąt lat zmiany w środowisku naturalnym będą już nieodwracalne. 


\section{REALIZATION OF THE PRINCIPLE OF SUSTAINABLE DEVELOPMENT IN POLISH ENVIRONMENTAL POLICY AFTER THE CONFERENCES IN RIO DE JANEIRO IN 1992 AND 2012}

Increase of the global population to 9 billion by 2050, as well as the number of middle-class people exceeding 3 billion by 2030, will not only lead to an increase in demand for different types of products, but also can cause enormous environmental degradation. The conferences, which took place in Rio de Janeiro in 1992 and 2012, surely played a huge role in shaping the concept of sustainable development in the international arena. Poland, as an active participant of both Earth Summits, also implemented legislation concerning the concept of sustainable development. However, for our country a crucial significance is seen in the policy in this regard shaped by the European Union. After joining the European Community, it was necessary to implement EU directives and to adjust national legislation to European law.

The subject of environmental protection and natural resources should be moved in the international scope. the future of the next generations and the future of the world depends on proper co-operation of states and environmental policy.

Keywords: Rio +20 , sustainable development, environmental policy 